McGill Law Journal

Revue de droit de McGill

\title{
Rafael Domingo, The New Global Law (Cambridge: Cambridge University Press, 2010)
}

\section{Pedro J. Martínez-Fraga}

Volume 56, numéro 3, april 2011

URI : https://id.erudit.org/iderudit/1005138ar

DOI : https://doi.org/10.7202/1005138ar

Aller au sommaire du numéro

Éditeur(s)

McGill Law Journal / Revue de droit de McGill

ISSN

0024-9041 (imprimé)

1920-6356 (numérique)

Découvrir la revue

Citer ce compte rendu

Martínez-Fraga, P. J. (2011). Compte rendu de [Rafael Domingo, The New Global

Law (Cambridge: Cambridge University Press, 2010)]. McGill Law Journal/

Revue de droit de McGill, 56(3), 767-773. https://doi.org/10.7202/1005138ar d'utilisation que vous pouvez consulter en ligne.

https://apropos.erudit.org/fr/usagers/politique-dutilisation/ 
BOOK REVIEW

Rafael Domingo, The New Global Law (Cambridge: Cambridge University Press, 2010).

\section{Pedro J. Martínez-Fraga*}

In his 2010 work entitled The New Global Law, Professor Rafael Domingo $^{1}$ asserts that international law, the science concerned with regulating and organizing the legal relationships among sovereign states, cannot serve to address the challenges of an integrated global community. The argument proposes that "classical" international law, true to its etymology suggesting a legal construct between and among nations, is inadequate for addressing transnational needs such as issues that are stateless in nature, since they affect humanity as a whole. Climate control, disease, abuse of power, infant mortality, vertical and horizontal nuclear proliferation, and corruption, to reference but a handful, are problems endemic to humanity and therefore transcultural and non-territorial. Professor Domingo argues that such challenges compel the creation and implementation of a global science of law that will serve as the law of humanity rather than the law of states.

Professor Domingo has identified transnational problems that cannot be addressed or redressed by the law of nations, but instead only pursuant to the application of a new global law or legal order, as a point of departure. In doing so, Professor Domingo cannot avoid confronting the doctrinal challenge of crafting a new normative foundation different and distinct from the law of nations, and the law among and between nations, while simultaneously ensuring that the traditional normative rubric of these systems remains preserved and harmonized with the "new global law". The task that Professor Domingo has endeavoured to undertake is daunting indeed. A global law that functions in pari materia with municipal and international law also requires an equally universal and harmo-

* Pedro J Martinez-Fraga received his BA from St John's College in Annapolis (Highest Honours) in 1984, a JD from Columbia University School of Law (Harlan Fiske Stone Scholar) in 1987, and has Licentiate (JD equivalent), Magister, and DEA degrees from the Universidad Complutense de Madrid. He is the Coordinator of International Dispute Resolution for Latin America and the state of Florida for the law firm of DLA Piper. He is an Adjunct Professor of Law at the University of Miami School of Law, a Visiting Professor at the University of Navarra School of Law in Pamplona, Spain and an Honorary Professor of Law of the Universidad de San Ignacio de Loyola in Lima, Peru.

(C) Pedro J Martínez-Fraga 2011

Citation: (2011) 56:3 McGill LJ 767 Référence: (2011) 56 : 3 RD McGill 767

1 Rafael Domingo is a professor at the University of Navarra in Pamplona, Spain. 
nizing normative rubric. The author believes to have tapped into this paradigm by focusing on the element of "human dignity" common to every individual and therefore to all global citizens. A law of humanity must find a normative foundation in what is most intrinsically human, which in the author's view appears to be the condition of dignity.

However, even within the narrow confines and limitations of The New Global Law, greater sustained analysis is required concerning the profoundly transcultural definition of "dignity"2 versus collective social virtues that do not and cannot aspire to rest within the concept of human individuality. Professor Domingo has certainly opened the door for doctrinal development of the normative premises of the bold new "global law", but he hardly crosses his own threshold from even the most modest analytical perspective. The jurisprudence and conceptual workings of a natural law resurgence ${ }^{3}$ merit more than just surface reference. Despite the ostensibly logical effect of this resurgence, Professor Domingo's grounding of the new global law may require another book or series of books.

In the sciences, as well as philosophy, and history, the world often misunderstands its most pressing and important issues, while neglecting others entirely. Indeed, Wilfred Jenks identified two concerns that have been misunderstood and altogether neglected:

(1) how far the law of nations will remain a traditional framework for the mutual relations of states as the basic units of political organization in a world in which states continue to guard jealously their sovereign independence, a law valued and respected as a necessary discipline for the mutual relations of states, but with little obvious direct impact on everyday life perceptible to the ordinary citizen; or (2) how effectively it will become a common law of mankind in a welfare world beyond the welfare state, fulfilling in a world community of peace and freedom a part comparable to that of a mature legal system in an advanced civilization. ${ }^{4}$

Writing along similar but distinct conceptual and phenomenological lines, Philip Jessup observed the following:

No system of law springs into existence full-panoplied. All legal systems from the most primitive to the most advanced have their backgrounds and roots in the society in which they govern. It is therefore not enough for the future of the international society to say that we must have a rule governing the use of atomic bonds and other weapons of mass destruction. It is not enough merely to have a law mak-

2 Rafael Domingo, The New Global Law (New York: Cambridge University Press, 2010) at $131-36$.

$3 \quad$ Ibid at 49.

4 C Wilfred Jenks, Social Justice in the Law of Nations: The ILO Impact After Fifty Years (London: Oxford University Press, 1970) at 1. 
ing war illegal. Such rules, even if backed by an adequate form of organization or government, would fail to create a well-ordered international society, the existence of which is a prerequisite to the successful functioning of any legal system. If there be no adequate body of law governing the solution of the conflicts which are inherent in any human relations, frictions and tensions will develop to a point which will bring about breaches of the primary rules about weapons and wars; even in the most highly developed societies, underlying inequities and resulting strains produce riots, revolutions, and civil wars. ${ }^{5}$

These propositions have also been the victims of both misunderstanding and neglect.

Professor Rafael Domingo, however, has blessed us with a work thatalthough shrouded in a mantel of modesty and labelled a mere "point of departure"-places in sharp relief the correct understanding and urgent sense of attention that must be accorded to the origin of a systematic response to the issues that Professors Jenks and Jessup have so aptly and concisely identified.

Secure in the conviction that neither a non-political nor a geopolitical revolution has reconfigured and transformed all societies, Professor Domingo boldly asserts that when confronted with the reality of globalization giving rise to an international society, "Perhaps this is the most salient difference from the past: the hectic pace of our social relations ... at times makes it difficult to adapt to the demands of justice."6 Developing this concept further, Professor Domingo observes, "Our society is the product of a complex mosaic of political, economic, and cultural relationships, the intricacies of which are hardly recognizable merely by applying the social norms of yesteryear."7

By juxtaposing the global society of the twenty-first century and its incidental challenges against a rubric of "international law" that is both procedurally and substantively ill-equipped to provide a holistic juridical response to the history-altering exigencies enumerated above, Professor Domingo underscores the friction and tensions that have spawned his definition of a global law. Mere recourse to "international law" is no longer enough. Only a transnational paradigm, according to Professor Domingo, would even begin to prepare a global society for the challenges that already assault it.

5 Philip C Jessup, A Modern Law of Nations: An Introduction (New York: The MacMillan Company, 1958) at 1-2.

6 Supra note 2 at xiii.

7 Ibid. 
The consequences of a transnational law cannot be avoided, however, and Professor Domingo does not shy from rising to the challenge and rescuing the proverbial gauntlet. Accordingly, his "point of departure", as the totality of this work is described, traces the contours of the ius gentium from its Roman origins and the concept's rich manifold nature during the middle ages, through to the development of the ius gentium al ius inter gentes and a ius gentium Europaeum. This exercise is not an irrelevant testament to extraordinary erudition and precise scholarship, nor is it an allocutio to the application of ancient doctrinal rubrics of a twenty-first century framework. To the contrary, Professor Domingo finds it necessary to delineate and highlight the configuration of normative tenets that rendered international law, or a ius gentium Europaeum, a viable historical construct by way of an exercise in phenomenology that may bring into relief the very unique manner in which a transnational global law is deeply steeped, and finds resonance, in aspects of the most fundamentally embedded principles of the science of the law.

The conceptual challenge that Professor Domingo raises for the reader, does not ignore the precepts of law and territoriality that govern municipal and international law to this day. Not surprisingly, in the context of this ambitious work, Professor Domingo courageously proposes the following:

The principle of territoriality is elementary, like a person's sense of touch. Even though it is easily surpassed in importance by sight and hearing, it remains useful and sometimes indispensable. Territoriality is to the law what occupation is to property, its first link. However, it is not the only nor most important one. The problem with the state is that its survival is conditioned on territory. Thus, international law, being a law between states, was staked first on the totalitarian hegemony of the principle of territoriality, thus weakening the principle of the person. ${ }^{8}$

In this same vein, Professor Domingo relentlessly asserts that

\begin{abstract}
sovereignty and universality are irreconcilable concepts, as are universality and totality. Globalization is universal. That is not true of the national-international pairing, which has governed modernity and is fighting to survive. ...Universality reclaims the idea of the person as its centerpiece and then immediately turns to the notion of people, once more, publicum ex privato. ${ }^{9}$
\end{abstract}

Unlike Ptolemaic astronomy, which purports "to save the appearances" by grafting epicycle onto epicycle, Professor Domingo demonstrates that his global law is a whole that affects all of its constituent parts-

$8 \quad$ Ibid at 75 .

9 Ibid at 71 [emphasis added]. 
namely, the concepts of territoriality, state, sovereignty, and person. The issue is not one of reconfiguring existing precepts so as to render viable a new concept of transnational law, but rather the compelling and necessary inferences that must be extracted from a normative order that transcends the mere governance of relationships between and within states. Thus, the author is impelled to demonstrate two propositions. First, a global law finds its genesis in the very language, nomenclature, and juridical concepts that for centuries capably addressed the concerns of an "international community"-albeit at the expense of the concepts of person and publicum. Second, while notions of statehood, sovereignty, and territoriality rightfully command a domain in directing the interworkings of nations, what were once appropriate historical pillars of international law are now but flawed premises of a global and transnational legal order that both defines and is defined by the afflictions of humanity instead of states, persons, and territory.

The difficult, and almost cruel, question cannot be ignored: To what extent is Professor Domingo's "point of departure" towards a global law more than a finely woven tapestry of historical exegeses framed by theoretical musings? The author answers the question without ever having posed it; as though it pervaded every page of his work.

It would be a blunder to pretend that the simple transposition of national legal norms and precepts onto a global juridical order would invite the creation of a global state akin to a Kelsenian paradigm that identifies both order and state. To this end, Professor Domingo notes:

The excessive concentration of power accumulated by a hypothetical State of Humanity would turn this conjecture into a dangerous and undesirable reality. On the other hand, it is possible to transfer some key principles of federalism, as well as of the EU [European Union], a supranational sui generis institution that has been able to combine various existing jurisdictional levels well. ${ }^{10}$

He further adds that a proposed global order shall commence by establishing a unum corpus subsuming municipal legal rubrics where, unlike international law, even superstates that are amenable to global law such as the European Union, shall have no recourse but to integrate it into their own ordo iuris. Municipal law would be rendered incomplete and wholly inadequate were it to ignore the strictures of global law.

The efficacy and practical application of Professor Domingo's propositions are more than intelligent theoretical chimeras. This point is accentuated in his fleeting but incisive reference to international commercial arbitration and lex mercatoria. While the former is viewed as serving as a 
temporary bridge until such time as transnational courts of civil procedure attendant to global law may come into being, it is abundantly clear in Professor Domingo's analysis of the subject that this historically necessary construct is far from a responsive development capable of serving humanity with a single voice that addresses global crises and concerns. As for lex mercatoria, although economic globalization has certainly given rise to a "transnational" lex mercatoria, ${ }^{11}$ the breadth and depth of this development is insufficient; lex mercatoria will never be fully capable of shedding the primacy of its mercantile and commercial nature. Neither the international arbitration constructs, nor the evolution, formation, and transformation of lex mercatoria, can serve as foundations akin to the global law that Professor Domingo espouses.

While this version of global law finds a normative voice in the concept of the person, Professor Domingo's analysis is not and does not purport to be a blueprint that may be readily applied to humanity. Viewed through this lens, it is clear that Professor Domingo's global law is far from a mechanical formula that can be easily implemented once grasped by the international community. However, by reinvigorating the possibility of universality, rooted in the particularity of the notion of person and in the totality of publicum, the reader is offered a concrete fulcrum on which to rest the lever that is to aid in the construction of a global law consistent with cultural and economic globalization, as well as with the transnational catastrophes now scarcely able to be identified much less addressed.

Amending the punctuation of Professor Domingo's title transforms it into a rather profound question: What is Global Law? ${ }^{12}$ After savouring the text, visiting and revisiting it, it becomes rather apparent that this title is anything but whimsical. Quite to the contrary, constructing the title as a question is a Socratic challenge to the reader, consisting of two very distinct components. First, the mere formal aspect of the question incites the need to resort to the Socratic principle of courage, because it is only when armed with Socratic courage that an endeavour initiated by a question of any magnitude can be undertaken in a spirit of complete commitment. To begin the entire analysis with a question is to warn the reader that good faith and total devotion to the cause may never lead to the mantel of certainty that accompanies a definitive answer. Second, the title and its text speak to the teaching of the ugliest man in Athens (a traditional description of Socrates himself) in that only an examined life merits liv-

11 Ibid ("[t]hrough commercial arbitration, a new lex mercatoria has been shaped-one applicable to international commerce" at 112).

12 Indeed, this was the original title of the Spanish version of this book: Rafael Domingo, ¿Que es el Derecho Global?, 2d ed (Pamplona, Spain: Thomson-Aranzadi, 2008). 
ing. ${ }^{13}$ Both principles are directly applicable to Professor Domingo's text. Endeavouring to develop the fundamentals of a global law, in part based upon the person and the collective publicum as a type of normativity, requires both reader and author to brace themselves for a daunting and imperative task in order to perpetuate a civilized international community. When the objective is for the most expedient resolution possible, the principle of uncertainty that accompanies every question may only be confronted pursuant to a summoning of courage. Yet, as the solution is grounded in the person, so too is the need for a solution and the problems generating this need, as these are the result of humanity's own workings and mishaps. Although scantly addressed in Professor Domingo's book, the crises that a global law must address all have one stark common denominator. They are all the consequences of human affairs, of men's own actions, omissions, and shortcomings. It is here that the Socratic examined life finds its relevance. ${ }^{14}$

We have now been provided with a "point of departure" towards a new global law. Do we have any other choice but to undertake the challenge, despite its endemic uncertainty and taxing demands?

13 Socrates's concept of the "examined life" is grounded in the principle that wisdom is found in the questioning of things and the Socratic method fundamentally questions truth. For a good summary of the concept of an "examined life", see Richard Kraut, "The Examined Life" in Sara Ahbel-Rappe \& Rachana Kamtekar, eds, A Companion to Socrates (West Sussex, UK: Wiley-Blackwell, 2009) 228. 